\title{
UNDERSTANDING DEMOTIVATING FACTORS ON EFL STUDENTS IN ONLINE LEARNING
}

\author{
Siti Maemunah ${ }^{1}$, Sidik Indra Nugraha ${ }^{2}$, Acep Bahrum Kamil ${ }^{3}$ \\ ${ }^{1}$ (English Education Department, Singaperbangsa University of Karawang, Indonesia). \\ ${ }^{2}$ (English Education Department, Singaperbangsa University of Karawang, Indonesia). \\ ${ }^{3}$ (English Education Department, Singaperbangsa University of Karawang, Indonesia).
}

* Corresponding Author. E-mail: ${ }^{1}$ maemunahsiti9471@gmail.com,

\begin{abstract}
Abstrak
Demotivation is a complex problem that many foreign language (FL) learners faced, and it is caused by a variety of factors including the teacher, poor self-esteem, and previous bad language learning experiences This study aimed to understand.d the demotivating factors on EFL students in online learning. The participants of this study were three students of the third grade of senior high school in Karawang. This study used a qualitative case study design to address the research objectives. The data for this study was gathered through semi-structured interview questions as an instrument of this study. The collecting data was obtained through Google meeting. The result of this study revealed that there are two demotivating factors on EFL students in online learning. Those are the teacher's methods and learning material. In this case, the researcher found out that those factors are from the external factors. In the teacher's method, there are two aspects that demotivate EFL students in online learning. The first aspect is because the teacher always speaks English all the time during learning. The second is because the teacher did not evaluate the students' assignments. The last factor is the learning materials, the students get difficult to understand the materials during online learning.
\end{abstract}

Keywords: demotivation factors, online learning.

\begin{abstract}
Abstrak
Demostrasi merupakan masalah kompleks yang pelajar bahasa asing hadapi dan disebabkan oleh beberapa factors termasuk guru, harga diri yang buruk dan pengalaman belajar bahasa buruk sebelumnya. Peneletian ini bertujuan untuk memahami faktor-fakto demotivasi pada siswa EFL dalam pembelajaran online. Partisipan dari penelitian ini adalah siswa sekolah menengah atas di Karawang. Penelitian ini menggunakan desain studi kasus untuk menjawab tujuan penelitian. Data dari penelitian ini dikumpulkan melalui pertanyaan wawancara semi terstruktur sebagai sebuah instrumen dari peneletian ini. Pengumpulan data dikumpulkan melalui google meeting. Hasil dari penelitian ini menunjukan bahwa terdapat dua factor demotivasi pada siswa-siswa EFL dalam pembelajaran online. Yaitu metode guru dan materi pembelajaran. Pada kasus ini, peneliti menemukan bahwa factor-faktor tersebut berasal dari factor eksternal. Pada metode guru, terdapat dua aspek yang mendemotivasi siswa EFL dalam pembelajaran online. Aspek pertama adalah, karena guru selalu berbicara bahasa inggris sepanjang waktu selama pembelajaran. Yang kedua adalah, karena guru tidak pernah mengevaluasi tugas-tugas siswa. Faktor yang terakhir adalah materi pembelajaran, siswa kesulitan untuk memahami mteri-materi selama pmbelajaran.
\end{abstract}

Kata kunci: Faktor demotivasi, pembelajaran online

\section{Introduction}

It's been a year since learning activities at school have turned into online learning due to the covid-19 pandemic, including English learning. During online learning, students are losing interest in learning English and getting increasingly 
Jurnal Edumaspul,5 (2), Year 2021 - 217

(Siti Maemunah, Sidik Indra Nugraha, Acep Bahrum Kamil)

demotivated as time passes. Demotivation occurs when a person's motivational energies are hampered or lost (Soureshjani \& Riahipour, 2012). also argued that demotivation is lacking deliberate effort, willingness, and investment for achieving a specific purpose in language learning. Demotivation is a complex problem that many foreign language (FL) learners face, and it is caused by a variety of factors including the teacher, poor self-esteem, and previous bad language learning experiences (BABA KHOUYA, 2018).

Students that are demotivated are less engaged and enthusiastic about their studies. A demotivated learner is someone who was formerly enthusiastic about learning. Motivation is one of these various aspects, yet he or she has lost interest for some reason.

Numerous studies on student demotivation variables in second language acquisition have been conducted. According to (Gorham \& Christophel, 1992), in their study by the title "Students' perceptions of teacher behaviors as motivating and demotivating factors in college classes" revealed that demotivating elements in college classrooms included boring teachers, grading and assignment dissatisfaction, negative response to the course and material, teachers' attitude toward students, dislike and perceived lack of relevance of the topic area, time of day, duration of the class, and personal concerns. In addition, (Meshkat \& Hassani, 2012) also revealed that "learning contents and material" and "teachers' competence and teaching styles" are moderate sources of demotivation. It was supported by Sakai and Kikuchi (2009) studies which found "Learning Contents and Materials" to be a demotivating element for high school pupils in their studies.

In the previous research, most of them focused on the traditional classroom. In this current research, the researcher wants to focus on demotivating factors in online learning. Therefore, this study aims to understand the demotivating factors on EFL students in online learning.

\section{Demotivation}

Demotivation can be thought of as the polar opposite of motivation. Students may face a variety of challenges in the field of education, particularly in the field of foreign language learning (EFL), such as learning environments, instructor approaches, and behaviors, improper materials, or a lack of learning facilities or equipment (Jahedizadeh et al., 2016) .
Dörnyei defines demotivation as "specific external forces that reduce or diminish the motivational basis of a behavioral intention or an ongoing action" (2001b, p. 143, as cited in (Meshkat \& Hassani, 2012)). External variables were identified as the primary causes of demotivation by (McDonough, 2003). On other hand, (Sakai \& Kikuchi, 2009) claimed that demotivation might be caused by internal factors such as a lack of intrinsic motivation and a loss of self-confidence. Demotivation is defined as a factor that "decreases students' energy to learn," as well as "the absence of a force that encourages pupils to learn." (Zhang, 2007). According to Ikeno, (2002, as cited in (Jahedizadeh et al., 2016)) negative attitudes about learning among classmates, feelings of inadequacy about one's competence, exam-oriented classes, a lack of choice and control over the information being learned, and distrust in teachers' abilities were all highlighted as demotivating influences. Trang and Baldauf (2007, as cited in (Rajabi \& Hosseini Pozveh, 2016) demotivation is described as "having a negative impact on students and preventing them from gaining expected learning outcomes" (p.100). There is the impact of demotivation, such as being more conspicuous when language learning occurs in an EFL context where, due to the lack of opportunity to communicate with native speakers, language learners don't have much intrinsic and integrative motivation (Soureshjani \& Riahipour, 2012). Therefore, students are increasingly not interested in learning English. Demotivation has direct educational ramifications, and with the growing importance of learning a foreign language, it is vital to look into the linked demotivators (Meshkat \& Hassani, 2012). When students lack motivation, they tend to be uninterested in learning. It has an impact on their behavior, causing them to become bored, frustrated, distracted, and aggressive (Raymond J. Wlodkowski and Margery B. Ginsberg, 2019) .

\section{Online Learning}

The term "online learning" refers to education that occurs over the internet. distance and not in a traditional classroom. "Most of the terms (online learning, open learning, web-based learning, computer-mediated learning, blended learning, mlearning, for ex.) have in common the ability to use a computer connected to a network, that offers the possibility to learn from anywhere, anytime, in any rhythm, with any means" (Cojocariu et al., 2014). According to (Dhawan, 2020), Online learning is defined as "learning experiences in synchronous or 
asynchronous situations using various devices (e.g., mobile phones, laptops, etc.) with internet access.", Because we can access online learning whenever we choose, it can be described as a tool that can make the teaching-learning process more student-centered, inventive, and flexible. Although the learning is conducted by virtual, but students can learn and communicate with teachers and other students from anywhere (independent) in these environments."(Singh \& Thurman, 2019). So, the learning process still can run well.

\section{Methode}

A qualitative case study design is used in this research to discover data from real-life situations. Case study was adopted because it focused on the specific phenomenon which is occurring in a reallife situation (Cousin, 2005). These participants were the students in the third grade of Senior high School in Karawang. Three students in total participated. The interview was used as an instrument guidelines. The researcher used semistructured interview questions. There are several questions to gain information from participants. The collecting data was obtained through Google meeting. For the analysis data, the researcher adopt the analysis technique from (Helaludin, 2019) as describe follows:

\section{Data Reduction}

Data reduction is a delicate thought process that necessitates a wide range of intelligence and understanding. The reducing data process is carried out by acquiring the results of interviews and observations. To offer the summary research results, the data would be selected, summarized, and highlighted.

\section{Data Display}

The process of presenting data after it has been reduced is known as data display. In qualitative research, data is presented in the form of summaries, charts, links between categories, patterns, and other visual aids so that the reader can understand it. Readers will be able to understand the concepts, classifications, relationships, and distinctions of each pattern or category more easily if the data is organized systematically.

\section{Conclusion}

The last step is drawing conclusions and verification. The study's conclusions must be able to propose solutions to the difficulties that have been posted, as well as data verification that reveals the genuine meaning of the data configuration.

\section{Findings and discussion}

According to the data of the interview, there are two findings of demotivating factors on EFL students in online learning. Teacher's method as demotivator of EFL students, and learning materials. The following is a detailed explanation of the findings.

\section{Teacher's method as demotivator of EFL student}

Somehow there are student who catches the learning quickly and there are students who catch the learning slowly. It occurs, because teacher always use full English in explaining the material as the method. The statement is evidenced by the participants' answers below.
Researcher : Does your teacher always use English language when delivering the learning?
Participant 1 : Yes, she always speak English when teaching. Sometimes I did not understand the lesson that has been taught by her.
Participant 2 : Yes, she always use English language when explaining the material. I don't mind if my teacher mix with Indonesia, because I do not have many vocabularies in English.

Participant 3 : Yes. Actually I do not understand what she is talking about, because I cannot speak English.

From the result interview above, showed that most of the students have trouble understanding words when their teacher speaks English all the time.

Beside, students get difficulty to understand the explanation of teacher. Students also get difficulty about the materials that not be reviewed by their teacher.

Researcher : Does your teacher after giving the assignment then discuss it?

Participant 1:.No, my teacher did not discuss the assignment.

Participant 2: No, my teacher always continue the new material without review the assignment.

Participant 3: No, my teacher never discussed the assignment. She only gives homework without discussing it. 
Jurnal Edumaspul,5 (2), Year 2021 - 219

(Siti Maemunah, Sidik Indra Nugraha, Acep Bahrum Kamil)

Based on the participants' answers above, students feel disadvantaged by the teacher's method of not reviewing the material, because not all students do not understand the material provided.

Researcher : Are you able to understand the material that your teacher has conveyed in learning English online?

Participant 1 : No, understanding the material during online learning is not as easy as online learning. It is difficult to ask the teacher if there is a matter that I couldn't understand.

Participant 2 : No. I'm more difficult to understand the new subject matter. I hope I can study offline as soon as possible.

Participant 3 : No, I didn't understand about the material because of limited signal and quota. It is getting more difficult.

Based on the outcome of the interview transcription, the student needs a longer time and signal to understand the material that has been taught by their teacher.

The current study of the findings revealed that the teacher's method is quite demotivating. They tended to remain silent if they did not comprehend what their teacher was saying and did not ask the teacher to repeat it since they were uninterested in English. The students were unable to understand the teacher's words since their teacher spoke English. They were also demotivated when the teacher did not clarify things in Indonesian. So the students will get nothing from the learning.

Besides, the students said that their teacher did not ever evaluate the assignment. How the students know if there is a problem or no from the materials. The teacher should be able to instruct the students in the order they will not do a mistake and it can improve their English skill by practice.

The results revealed that learning materials are including in demotivating factors of EFL students in online learning. This finding is similar to (Chambers, 1993) study who found that learning content (or the textbook) was a significant demotivator along with the teachers. Another result study is found in (Sakai \& Kikuchi, 2009) found out that, "learning subjects and resources" was a demotivating

\section{Learning materials}

During online learning the students face some problem in English learning exactly in learning materials.

factor for high school students. From the "difficult" words that have been said by the teacher, it means that most of the students cannot achieve the materials well. The students faced several problems in online learning such as limited signal and quota, even they can be distracted by their family or environment.

\section{Conclusion}

Based on findings and discussion in this study, it can be concluded that there are two factors that demotivating EFL students in online learning. Those are the teacher's methods and learning material. In the teacher's method, there are two aspects that demotivating EFL students in online learning. The first aspect is because the teacher always speaks English all the time and the second is because the teacher did not evaluate the assignment. For the learning materials, the students get difficult to understand the materials during online learning.

\section{References}

BABA KHOUYA, Y. (2018). Students Demotivating Factors in the EFL classroom: The Case of Morocco. Advances in Language and Literary Studies, 9(2), 150. https://doi.org/10.7575/aiac.alls.v.9n.2p.150

Chambers, G. (1993). Taking the 'de' out of demotivation. Language Learning Journal, $7(1)$, 13-16. https://doi.org/10.1080/09571739385200051

Cojocariu, V.-M., Lazar, I., Nedeff, V., \& Lazar, G. (2014). SWOT Anlysis of E-learning Educational Services from the Perspective of their Beneficiaries. Procedia - Social and Behavioral Sciences, 116, 1999-2003. https://doi.org/10.1016/j.sbspro.2014.01.510

Cousin, G. (2005). Case study research. Journal of Geography in Higher Education, 29(3), 421427.

https://doi.org/10.1080/03098260500290967

Dhawan, S. (2020). Online Learning: A Panacea in the Time of COVID-19 Crisis. Journal of Educational Technology Systems, 49(1), 5- 
22.

https://doi.org/10.1177/0047239520934018

Gorham, J., \& Christophel, D. M. (1992). Students' Perceptions of Teacher Behaviors As Motivating and Demotivating Factors in College Classes. Communication Quarterly, 40(3), 239-252. https://doi.org/10.1080/01463379209369839

Helaludin, H. W. (2019). Analisis Data Kualitatif: Sebuah Tinjauan Teori dan Praktik.

Jahedizadeh, S., Ghanizadeh, A., \& Ghonsooly, B. (2016). The role of EFL learners' demotivation, perceptions of classroom activities, and mastery goal in predicting their language achievement and burnout. AsianPacific Journal of Second and Foreign Language Education, 1(1), 1-17. https://doi.org/10.1186/s40862-016-0021-8

McDonough, S. (2003). Teaching and Researching Motivation. In ELT Journal (Vol. 57, Issue 3). https://doi.org/10.1093/elt/57.3.308-a

Meshkat, M., \& Hassani, M. (2012). Demotivating factors in learning english: The case of iran. Procedia - Social and Behavioral Sciences, 31(2011), 745-749. https://doi.org/10.1016/j.sbspro.2011.12.134

Rajabi, B., \& Hosseini Pozveh, S. M. (2016). A Quantitative Analysis of Demotivating Factors for Iranian Intermediate High School EFL Learners. Mediterranean Journal of Social Sciences, March. https://doi.org/10.5901/mjss.2016.v7n5p124

Raymond J. Wlodkowski and Margery B. Ginsberg. (2019). Teacing Intensive and Accelerated Courses: Instruction That Motivates Learning. In Journal of Chemical Information and Modeling (Vol. 53, Issue 9).

Sakai, H., \& Kikuchi, K. (2009). An analysis of demotivators in the EFL classroom. System, $37(1)$, $57-69$. https://doi.org/10.1016/j.system.2008.09.005

Singh, V., \& Thurman, A. (2019). How Many Ways Can We Define Online Learning? A Systematic Literature Review of Definitions of Online Learning (1988-2018). American Journal of Distance Education, 33(4), 289306.

https://doi.org/10.1080/08923647.2019.1663 082

Soureshjani, K. H., \& Riahipour, P. (2012). Demotivating factors on English speaking skill: A study of EFL language learners and teachers' attitudes. World Applied Sciences Journal, 17(3), 327-339.

Zhang, Q. (2007). Teacher Misbehaviors as Learning Demotivators in College Classrooms: A Cross-Cultural Investigation in China, Germany, Japan, and the United States. Communication Education, 56(2), 209-227.

https://doi.org/10.1080/03634520601110104

\section{About author(s):}

${ }^{1}$ Siti Maemunah is a student of English education department from University of Singaperbangsa Karawang.

${ }^{2}$ Sidik Indra Nugraha is an author's first advisor in Faculty of Teachers Training and Education of Singaperbangsa University of Karawang.

${ }^{3}$ Acep Bahrum Kamil, S.Pd., M.Pd is an author's second advisor in Faculty of Teachers Training and Education of Singaperbangsa University of Karawang 